\title{
The Health Promotion Model of Public Health Program for Elderly
}

\author{
Arita Murwani ${ }^{1}$, Santoso ${ }^{1}$, Eny Lestari ${ }^{1} \&$ Endang S. Sulaeman ${ }^{1}$ \\ ${ }^{1}$ Post Graduate Program, Sebelas Maret University, Surakarta, Indonesia \\ Corresnpondensce: Arita Murwani, Ir. Sutami Street Number 36 A, Jebres, Pucangsawit, Surakarta, Central Java, \\ Indonesia. Tel: 62-812-2585-734. E-mail: nursearita76@gmail.com
}

\author{
Received: May 4, 2019 Accepted: May 29, 2019 Online Published: June 17, 2019 \\ doi:10.5539/gjhs.v11n7p119 \\ URL: https://doi.org/10.5539/gjhs.v11n7p119
}

\begin{abstract}
Objective: The society health care of elderly is integral part of service health by comprehensive through promotion, preventive, curative and rehabilitative, and resocialitative efforts. The aim of society health care is to improve the ability of society to live healthy until an optimal degree of health is achieved.

Method: This research was cross sectional research by using survey method. Sample of this research was 200 elderly that was divided into 25 clinics in Sleman regency of Special Region Yogyakarta. This research was done on March up to August 2018. The data was collected then processed by using PLS SEM program.

Resutls: The results of research show there is an influence between the health promotion and the health education with estimates $=0,753$. The health education posses the elderly health behavior with value $p=0,00$. The health behavior $(\mathrm{p}=0,00)$, public policy $(\mathrm{p}=0,07)$, the care function of elderly $(\mathrm{p}=0,00)$, and elderly behavior $(\mathrm{p}=$ $0,020)$ posse the independence of elderly. The elderly independence possess the elderly health quality with estimates as big as 0,312 .

Conclusion: Based on the finding of the study, elderly health quality can be improved by increasing the elderly independence through the health education effort which takes effect to the health behavior and improving the facilities and infrastructure related to the health public policy, and improving the health care of society.
\end{abstract}

Keywords: care function, policy, health education, health behavior, elderly

\section{Introduction}

Elderly is age group of 60 years which goes into the end step on life cycle (WHO, 2015). This phase will be gotten by everyone so it cannot be avoided. Elderly will experience the aging process biologically and it is marked by emergence of many changes in cognitive, physic, and psychology (Abidin, Nurdiana, Ahmad, \& Munir Rabin, 2016). Commonly, the psychological changes happened is a decrease in the ability and social functions possessed. The physic change is normal process but it often becomes threatening integrity for all of elderly like hair to be white, wrinkles appear on the skin, decreased body immunity, and decreased sensory function (Erawati, 2012).

The elderly population number in the world is $11,7 \%$ of the total population and it is estimated that this number will increase with increasing life expectancy (WHO, 2015). The total population of elderly in 2009 about 7,49\% and in 2011 increase to be 7,69\%. In 2000, the age of life expectancy in the world is 66 years then it increases to 70 years (in 2012), and 71 years (in 2013). The elderly health quality will increase when family member working together to do family function in health field. Some functions of family that is meant those are effective, social, reproduction, economic, and health care functions (Kemenkes, 2018). There are five main tasks of family to do the family function which posses to the health care, they are (a) identify health problems, (b) make decisions for elderly people who have health problems, (c) care for elderly people who are sick, (d) create a home environment that has an impact on health family, (e) use the health facilities closest to where you live (Friedman, 2010).

Public health care is an effort to provide nursing services that are an integral part of health services carried out by nurses by involving other health teams and communities to obtain higher levels of health from individuals, families and groups (Choi Young, 2016; Ding et al., 2015). Public health care for the elderly is a special field of nursing which is a combination of nursing, public health and social sciences which are an integral part of health services provided to individuals, families, special groups of elderly people and communities both healthy and sick (having comprehensive health / nursing issues through promotive, preventive, curative, rehabilitative, and resocialitative efforts aimed at the elderly by involving the active role of the community in an organized manner, such as the 
integrated-health-post for the elderly (Chang, 2014).

This research aims to analyze the influence between health promotion, elderly public policy, elderly care function, health education, and elderly behavior towards elderly independence and life quality to formulate the health promotion in public health nursing as a means to improve elderly health quality through elderly health nursing program in Sleman Regency, Special Region Yogyakarta by identifying health issues and nursing which is faced, decide the health problems or nursing and problem priority, specifically namely identifying health and nursing problems faced, establishing health or nursing problems and prioritizing problems, formulate the various alternative solutions to nursing problems that they face, assessment of health outcomes in solving health / nursing problems, encourage and increase community participation in health/nursing services, improve ability to maintain health independently (selfcare), instil healthy behavior through health education efforts, handling high risk groups which are prone to health problems, high risk groups including the elderly (Notoatmodjo, 2013).

The goals of public health care are individuals, families, groups and communities that have health problems due to factors of ignorance, unwillingness and inability to resolve health problems. Individual is a part of family member. If the individual has a health/nursing problem because of the inability to care for himself by something, it will affect other family members physically, mentally and socially (Friedman, 2010).

As a health effort in increasing the independence of the elderly can be seen from the health quality. The health efforts include the health promotion through health education which aims to change behavior which includes knowledge, attitudes, and practices (Orem, 2011; Kemenkes, 2015).

\section{Research Method}

This research used cross sectional design because data retrieval was done in same time (Sugiyono, 2014). There are 103,686 elderly aged 60-74 years old who live in 25 Health Center in Sleman Regency (Dinas Kesehatan Sleman Regency, 2016) (Badan Pusat Statistik DIY, 2015). This research sample is 225 elderly. This research aims to analyze the influence between health promotion, elderly public policy, elderly care function, health education, and elderly behavior towards elderly independence and life quality to formulate the health promotion in public health nursing as a means to improve elderly health quality through elderly health nursing program in Sleman Regency, Special Region Yogyakarta. The variables used for this research are health promotion (X1), good public policy (X2), function of elderly health nursing (X3), health education (Y1), elderly health behavior (Y2), elderly independence (Y3), and elderly health quality (Y4). The questionnaire used to identify the health quality (HTQL) is a questionnaire that is taken from sf- 36 from WHO. The function of health nursing program uses standard questionnaire from Friedmann. Index Katz is a standard instrument used to measure the independence while validity and reliability test are used to measure the healthy public policy, community empowerment and health education. PLS SEM is used to analyze by modelling dependent variable (X) and independent variable (Y).

\section{Result}

The table of summary results directly from latent variables

Table 1. Summary of results directly from latent variables

\begin{tabular}{llll}
\hline Direction of influence & Estimates & p-value & Conclusion \\
\hline The health promotion program $\rightarrow$ The health education & .753 & $2.33 \times 10^{-42}$ & Significant \\
The health education $\rightarrow$ The health behavior & -.226 & .000 & Significant \\
Public policy of elderly $\rightarrow$ Elderly independence & .184 & .007 & Significant \\
The nursing function of elderly $\rightarrow$ Elderly independence & -.228 & .000 & Significant \\
The health education $\rightarrow$ Elderly independence & .200 & .002 & Significant \\
Elderly behavior $\rightarrow$ Elderly independence & .164 & .020 & Significant \\
Public policy of elderly $\rightarrow$ Elderly health quality & -.036 & .587 & Non-significant \\
The nursing function of elderly $\rightarrow$ Elderly health quality & .121 & .067 & Non-significant \\
The health education $\rightarrow$ Elderly health quality & .061 & .366 & Non-significant \\
Elderly independence $\rightarrow$ Elderly health quality & .312 & $7.67 \times 10^{-6}$ & Significant \\
\hline
\end{tabular}

The estimated coefficients on the path analysis at the $5 \%$ real level of the bootstrapping resampling result show a 
significant effect for several variables. The relationship between latent variables that have a p-value of more than 0.05 indicates a non-significant relationship.

Based on the table above, it can be done the hypothesis testing. The testing is done on ten (10) hypotheses. T-Statistics value which is more big than 1.96 or p-value smaller than 0.05 , it marks that there is significant influence between latent variable. The original sample values same as estimated value relation between latent variable. If the positive original sample value indicates that the relationship between the latent variables is positive and vice versa.

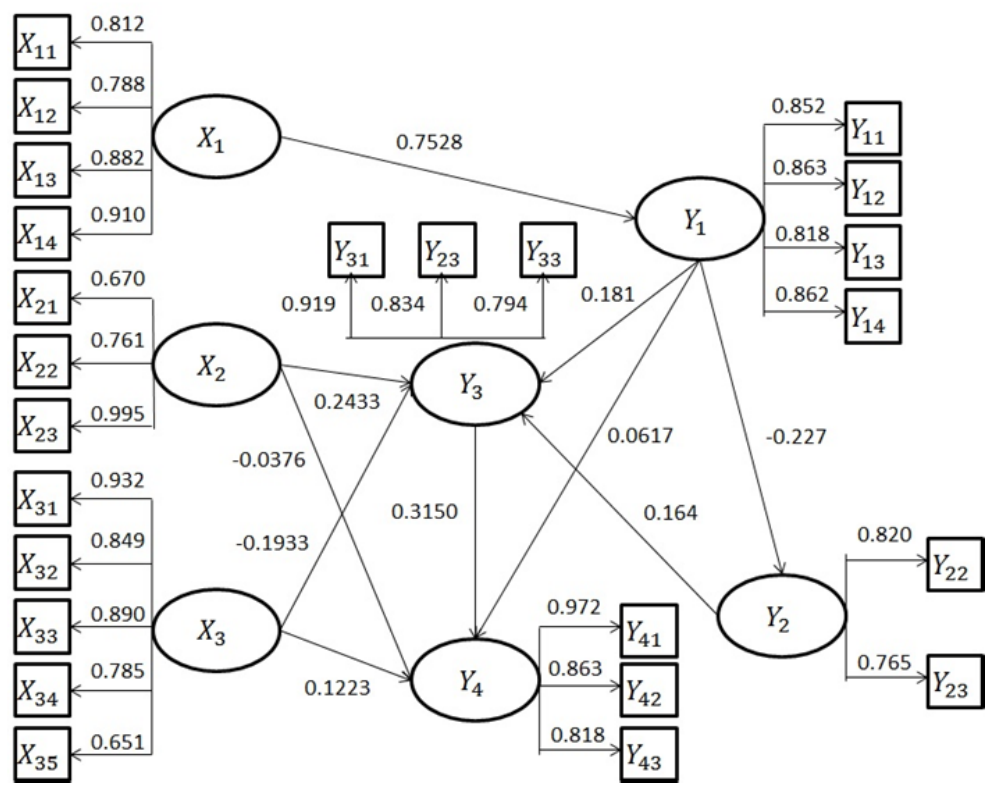

Figure 1. The value of loading factor for each indicator

\subsection{Model Evaluation}

The structural model describes the relation between latent variable. The goodness of the structural model is seen based on the coefficient of determination $(R-$ square $)$, predictive relevance $(Q-$ square), goodness of fit $(G o F)$, and testing statistic $\mathrm{t}$ through resembling bootstrapping.

\subsubsection{Coefficient of Determination ( $\mathrm{R}$ - Square)}

The latent variable of health education has a value $R$ - square as big as 0.5666 so the latent diversity of health education variables can be explained by health promotion programs as big as $56.66 \%$ and the rest as big as $43.34 \%$ can be explained by other factors out of the research. The variable of elderly behavior has a value $R-$ square as big as 0.0513 , it means that the diversity of elderly behavior can be explained by health education as big as $5.13 \%$, and the rest $94.27 \%$ can be explained by other factors out of research. The value $R-$ square for the variable of elderly behavior is very low. The variable of elderly independence has a value $R$-square as big as 0.1418 , it means that the diversity of elderly behavior can be explained by public policy, nursing function of the elderly that means the diversity of elderly independence can be explained by public policy, nursing function of the elderly, health education and elderly behavior as big as $14.18 \%$ and the rest $85.82 \%$, it is explained by other factors out of the research. The last, the variable of elderly health quality has a value $R-$ square as big as 0.1009 which means that the diversity of elderly health quality can be explained by the public policy of elderly, nursing function of the elderly, elderly education, and elderly independence as big as $10.09 \%$ and the rest 89.91 can be explained by other factors out of the research. The value $R-$ square as big as 0.26 is classified strong, 0.13 medium, and 0.03 low (Akter, Samad, \& Zaman, 2013; Götz, 2010).

\subsubsection{Predictive Relevance ( $\mathrm{Q}$ - square)}

The value $Q-$ square that is gotten is as big as 0.6827 . The value $Q-$ square that it is bigger than 0 marks that latent variable already could predict the good model. The output of program $\mathrm{R}$ version 3.4.2 does not output the value $Q$ - square, so the value $Q$ - square can be counted manually as below. 


$$
\begin{aligned}
Q-\text { square } & =1-\left[\left(1-R_{1}\right)\left(1-R_{2}\right)\left(1-R_{3}\right)\left(1-R_{4}\right)\right] \\
& =1-[(1-0.5666)(1-0.0513)(1-0.1418)(1-0.1009)] \\
= & 0.6827
\end{aligned}
$$

Goodness of $f(x)=a_{0}+\sum_{n=1}^{\infty}\left(a_{n} \cos \frac{n \pi x}{L}+b_{n} \sin \frac{n \pi x}{L}\right)$ Fit $(G o F)$

The value of $G o F$ is between 0 up to 1 . As high as the value $G o F$ states that the model is better. The value of $G o F$ which is gotten from this model is 0.3803 . GoF as big as 0.38 includes into high category so this model has the good performance and validate the overall model (Akter, Samad, \& Zaman, 2013; Husein, 2013; Henderson, Willis, Xiao, \& Toffoli, 2016).

\section{Discussion}

\subsection{The Effect of the Health Promotion Programs to Health Education}

The health promotion programs is the effort which is done by community although they want to and able to keep and increase their health together with the aim of health education that is increase the willingness or ability of society in health behavior, so it is relevant as this research that the health promotion programs relate with the health education. In addition to education as a media for health promotion programs, health education is also the target of health promotion programs to increase public knowledge through health education.

The health promotion gives the influence to give influence towards skills, knowledge, social relations with other people, the potential of individuals, and communities, especially the elderly. This approach to health promotion programs is an ideal opportunity for both government-owned and private health care facilities to respond the challenges which are faced by the elderly. Although many factors influence each other but also show the potential elderly can measure health status with the frequency of these elderly people attending health education (Henderson, Willis, Xiao, \& Toffoli, 2016; Ding et al., 2015).

The goals of health education are mentioned namely individuals, families, groups and communities. Elderly as an input in the process of health education is very much influenced by many factors, their own age, illness, environment, family support etc (WHO, 2015). Based on Skinner in the process of health education there is a process that is "learning", it is individuals who do not know to know (Skinner, 1938). Learning domains have three components, namely cognitive, affective and psychomotor. These three components greatly influence the outcome of learning. While the factors that influence learning include external factors such as light, sound, air humidity and temperature, while internal factors such as physiology, psychological (Notoatmodjo, 2013).

\subsection{The Effect of Health Education on Elderly Health Behavior}

The health education is provided to the elderly, especially those who are vulnerable to the risk of falling or vulnerable to an illness. Health education provided to the elderly must also pay attention to various factors including age, gender, occupation, and lifestyle (Notoatmodjo, 2013). Elderly people who live in the area of Sleman Regency mostly live in rural areas with jobs as farmers.

Geographically, the elderly who live in Sleman Regency tend to have a simple lifestyle, "nrimo" (receive) although the health education that is given appropriate by habitual action which is done by elderly. Health education influence towards health behavior to the resident in China about uncontagious disease (Ding, Shen, Zhang, Qi, \& Jiao, 2015). The residents who live in the rural area of Australia concerns more to the simple life factor than in the city. Primary health education or effective intervention program is given to improve knowledge towards the rural women about the risk of heart disease and the life style change (Crouch, 2011).

\subsection{The Effect of Public Policy on the Independence of the Elderly}

Respondents of this study namely the elderly said that public policies such as referrals to health facilities, treatment, home care, social security cards, old age social assistance, health information systems, which are in the health center working area of Sleman Yogyakarta Regency run and are in a good category. This research was supported by a previous journal which stated that one of the health policies of the government was the National Health Insurance (Jaminan Kesehatan Nasional/JKN). This policy aims to enable all communities to receive equitable and equitable health services by using a premium system such as health insurance in general (Kemenkes, 2018).

The research conudcted in Health Center of Sleman Regency shows that public policy influences towards elderly autonomy, such as health insurance factor - BPJS. Elderly can use the health service facilities in health center for free. Hence, elderly can do the promotive and preventive efforts to improve their independence.

The issue of public policy is based on the needs of problem solving that occurs in the society. Public policy is set by 
stakeholders, especially government that is oriented to the fulfillment of society needs and interest.

The public policy related to medical care service towards elderly is related to the elderly independence. The public policy about Japanese health insurance system has been used since 1961 and long-term care covers well-being service that is separated from medical care insurance scheme in 2,000 when Japan had been admitted as aging society. This policy aims to build comprehensive support service until the end of time of elderly in every community (Liu, C. Wang, Hu, \& W. Wang, 2018).

\subsection{The Effect of Nursing Function on Independence}

Family nursing care as a primary nursing function is expected to increase family independence in preventing and overcoming various family health problems (Kemenkes, 2018). Family care that functions as a basic essential function in the family have full responsibility to maintain the health status of the family members. Based on the results of the research, nursing functions affect the independence of the elderly by $52 \%$. Factors that can influence the implementation of health care functions in the family include lifestyle, healthy environment and preventive health assessment to provide information that supports and identifies risk factors in order to develop a health care plan (Friedman, 2010). Family nursing care that is carried out effectively can increase family independence (Agrina \& Zufitri, 2012). Family members who are able to provide care to sick elderly people can play an important role in the health and well-being of the elderly to implement a comprehensive approach (Parmar, Jacqueline, Suzette, \& Lesley, 2018). Efforts to guide and guide the family greatly influence the achievement of the independence of family members including the elderly in overcoming various health problems in the family. This is because family nursing care is a series of activities to transfer knowledge and the ability of the family to overcome existing health problems by using various strategies to change behavior towards a better direction (Rina, Jumita, Azrimaidaliza, \& Rizanda, 2012). The strategies or methods used include health education using verbal, psychomotor (practice) and affective to see the extent to which family compliance with activities that address health problems in the family (Basuki, Agus Tri, \& Prawoto, 2016).

\subsection{The Effect of Health Education on Independence}

A person's cognitive functions are very important in memory and most will affect daily activities (Muszalik, 2012). Education is the basis of intellectual knowledge possessed by someone, the higher the education will be the greater the ability to absorb and receive information. Extensive knowledge and insight is one of the factors behind the actions that will affect a person's behavior. The results of this study indicate the influence of health education on the independence of the elderly. Elderly people in Sleman Regency who often participate in integrated-health-post activities or who often visit health care facilities and get health education show independence, especially in terms of daily activities (activity daily living). In Iran, health education given to the elderly, especially those who suffer from diabetes, has an influence on the independence of the elderly in self-care. Independence in the elderly will have an impact on quality of life related to health (Ghasemi, 2019). This activity can be useful for maintaining joint function (physical health), so that it can improve fitness and improve feelings of well-being and support independence.

\subsection{The Effect of Health Behavior on Independence}

The results of this study indicate the influence of health behavior on the independence of the elderly. The elderly in this study were on average able to carry out daily activities and were active in integrated-health-post activities so that they were involved in direct socialization with the surrounding environment including with health workers. The social involvement of the elderly in the community can improve the physical health and mental health of the elderly by changing their health behavior and facilitating access to health care facilities and meeting with health workers so as to increase their independence. In China it shows that relatives, friends or neighbors are a source of social support and can monitor a person's health behavior, the researchers get significant and consistent results that social networks can regulate health behavior (Wu et al., 2017). The tendency of the elderly to carry out this healthy behavior will have an impact on independence which is not easy to depend on others. The social involvement of the elderly in the community can improve the physical health and mental health of the elderly by changing their health behavior and facilitating access to health care facilities and meeting with health workers so as to increase their independence (Vorst et al., 2017).

\subsection{The Effect of Public Policy on Health Quality}

There is no significant influence between public policy and the quality of health of the elderly. It can be shown that the elderly who do or enjoy health care facilities at the health care still have elderly people whose health status and quality of health are not good. The health quality of the elderly consists of physical health, mental health and health transition. Healthy public policy for the elderly in Indonesia has not all benefited the elderly, in Sleman regency 
there are only 9 elderly health clinics from 25 health centers, but the remaining 14 health centers have run elderly health programs, this is evidenced by the ease of access in each health center, but not all elderly people can use this well. Many influencing factors include knowledge of the elderly about the facilities in the health center, information that is not obtained by the elderly, family members who do not deliver to the health center so that the elderly are reluctant to visit the health center.

\subsection{The Effect of Function Care on Quality of Health}

There is no influence between the health care function and the quality of health of the elderly. Based on the data obtained by researchers the factors that influence this include chronic conditions in the elderly, decision-making styles and discharge planning when the elderly are in hospital care. The researcher concluded that the care function of the elderly in the less category and the quality of health of the elderly in sufficient categories so that the effect was less meaningful, this happened because of several factors that influenced the functioning of the health care program from each family who had an elderly live alone at home. Elderly people who live with many families who feel lonely because they are left behind by children who have worked and grandchildren who go to school, so they feel that no one is paying attention or recognizing problems related to the health of the elderly. Factors that affect the quality of health of the elderly, namely age, sex, education, employment, income, marital status and social activities also affect the condition of the elderly, this condition greatly affects both the elderly who live with family or live alone. Researchers and policy makers must explore the potential benefits of providing support and receiving support.

\subsection{Effect of Health Education on Health Quality}

There is no influence between health education and the quality of health of the elderly. The researcher explained that there are factors that make the obstacle that health education does not affect the quality of health. These factors include gender, lifestyle and marital status (Mofrad, 2015), other factors that can influence are problems related to the elderly, abilities and potential of the elderly and the level of health of the elderly (Kementerian Koordinator Bidang Pembangunan Manusia dan Kebudayaan RI, 2015). Elderly people slowly began to withdraw both physically, psychologically and socially. The most noticeable decrease is limitations in physical activity, especially in stamina and health. As the physical condition decreases, the elderly need a variety of public facilities so that the elderly will tend to withdraw from their environment. Indirectly this decrease in stamina will affect psychological conditions because they feel unable to live as before and encourage clans to withdraw and focus in their own lives. It has resulted in the failure of health education given to the elderly so that it does not affect the quality of life of the elderly (Friedman, 2010; 2012).

\subsection{The Effect of Independence on Health Quality}

There is an influence between independence and the quality of health of the elderly. According to researchers, reactivating the elderly can affect quality of life or living arrangements with up to 12 months. Elderly people who use health care facilities are less likely to get higher individual care facilities than people who receive care in ordinary health care facilities for 24 months. Although there may be a reduction in the total cost of nursing home care and health care programs for 24 months (reablement: AUD 19,888; usual care: AUD 22,757; 1 trial with 750 elderly), researchers have not found significant results between the size and importance of the effects of this study because the results proved to be very low quality of life. Independence in terms of daily activities is also considered an important indicator in terms of the health of the elderly, whereas dependence on daily activities correlates with an increase in the risk of death and poor quality of life for the elderly (Henderson, Willis, Xiao, \& Toffoli, 2016). It is recommended for the elderly to continue to carry out daily activities independently at home even though there are physical weaknesses. To support or improve health, effective interventions need to be developed through health promotion programs (Halcomb, Stephens, Bryce, Foley, \& Ashley, 2016).

\subsection{Community Nursing Health Promotion Model for the Elderly Through the Health Care Function Model}

\subsubsection{Step of Input}

The health quality of the elderly starts from health promotion efforts. Health promotion includes health human resources, program funds, media health promotion programs and the intensity of health promotion programs that are carried out continuously so that they can improve the quality of health of the elderly well. In addition, the existence of public policies related to the health of the elderly will further increase the independence of the elderly who will have an impact on the quality of the health of the elderly.

\subsubsection{Step of Process}

Health education as part of a health promotion program in the form of intervention, health promotion is born from 
health education. Health education that aims to change the behavior of individuals, groups and society is not enough to improve health status because there are still many factors or determinants that affect health and are outside the health area. Health promotion is a process of changing behavior or a planned learning process in individuals, groups or communities in improving their abilities (knowledge of attitudes and practices) to achieve optimal levels of healthy living. The process of health promotion includes schedules, the appearance of organizing officers and the environment into a unity that cannot be separated.

\subsubsection{Output Stage}

The results obtained from health education which is part of a health promotion program are knowledge, attitudes and practices related to health in the elderly. These goals: a) Make health as a value in society, b) Help individuals and families to be able to be independent or in groups to hold activities to achieve healthy life goals c) Encourage developing and using the appropriate health service facilities.

\subsubsection{Out Come Stage}

Individuals continue to learn to be independent in dealing with various circumstances in the environment so they are able to think and act on their own. The independence of individuals can support and choose a way of life to develop for the better. The level of independence of the elderly can be seen from the quality of life they have. The quality of life of the elderly can be assessed from the ability to carry out daily activities or activity of daily living.

\subsubsection{Impact}

Quality of life is a condition that describes the elderly to enjoy well-being including feeling all the events that occur in life. Elderly people who can achieve high quality of life can be interpreted that the life of the individual leads to a state of well-being but if the elderly have a low quality of life then the life of that individual is in a state of ill-being. Welfare is one of the parameters of the high and low quality of life of the elderly to enjoy old life. Improving the quality of life of the elderly aims to provide opportunities for the elderly who have the potential, empower the productive elderly and improve and strengthen the faith and piety of the elderly towards the Almighty God according to his beliefs

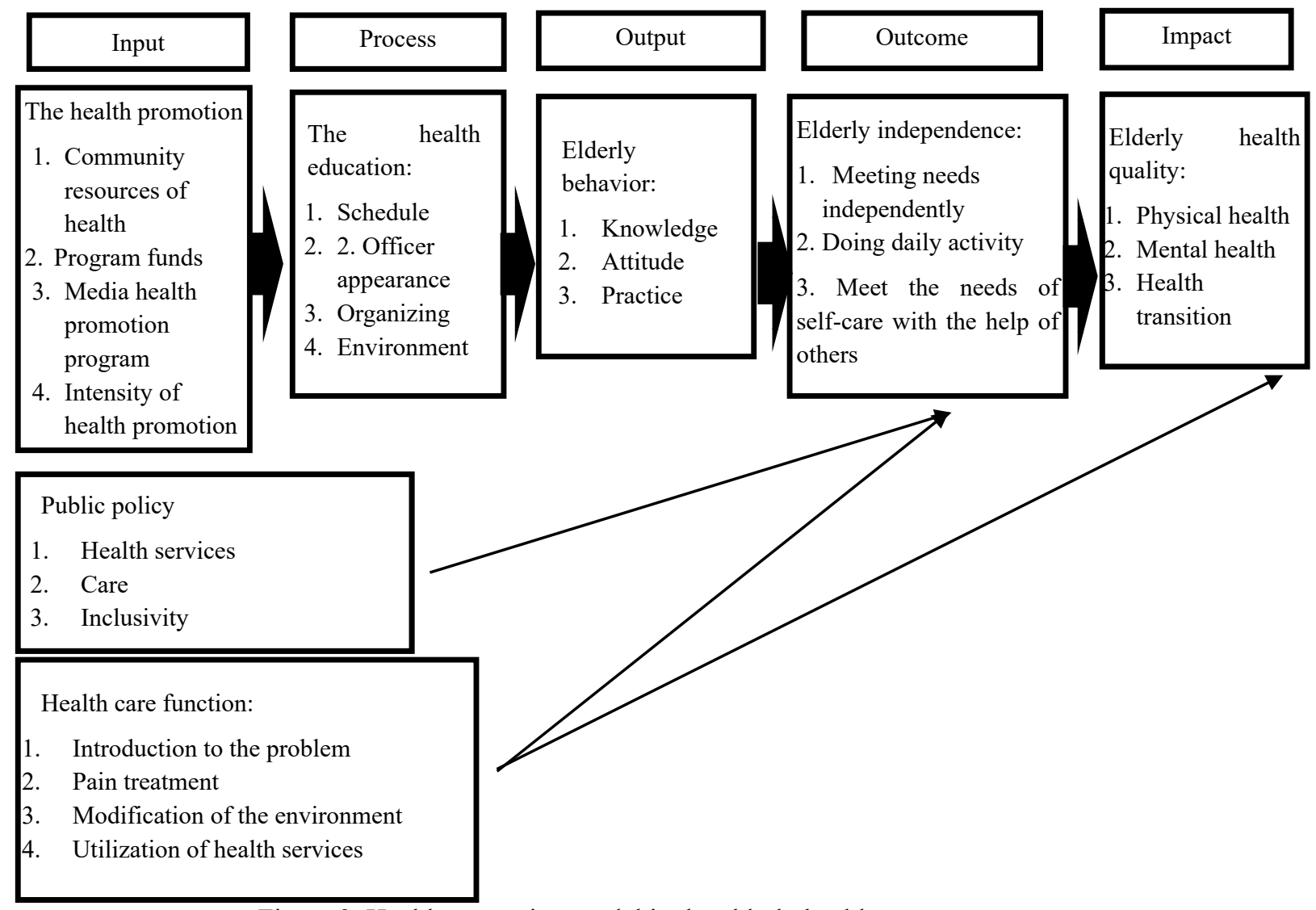

Figure 2. Health promotion model in the elderly health care program 


\section{Conclusion}

The model of the influence of health promotion programs, health behavior and independence of the elderly on the quality of health of the elderly proved to be fit with the data. The health quality of the elderly can be improved by increasing the independence of the elderly through health education efforts that affect health behavior and improving facilities and infrastructure related to public health policy and improving the function of public health care.

This research also explores the factors of local government support in making policies. The Regency Government of Sleman in improving the quality of elderly health and independence in the health of the elderly, among others by providing a budget for special care programs for elderly health through the launching of the Elderly Community Health Centres to appoint nurses to carry out public health care and provide facilities in government health facilities and governmental organization that provides easy access for the elderly (inclusiveness). This is the value of increasing the quality of elderly health in Sleman Regency. So, life expectancy in Sleman Regency occupies the highest ranking in the Yogyakarta Special Region and National level.

The low quality of life according to researchers is not necessarily significant whether reactivating the elderly can affect quality of life or living arrangements with up to 12 months. The change of elderly behavior is a function of the efforts of focused and integrated health education, both in terms of activity schedules, appearance of health workers, organization of neat health education and a conducive community environment. Therefore, in developing health promotion programs in Sleman, the availability and quality of human resources, the policy of providing budgets / funds from local governments, the use of information technology-based media and the frequency of health promotion for the elderly will have an impact on the better life quality of the elderly.

\section{Competing Interests Statement}

The authors declare that there are no competing or potential conflicts of interest.

\section{References}

Abidin, N. A., \& Munir Rabin, D. S. (2016). Associations Between Tri-Axial Accelerometer-Determined Physical Activity and Self-Reported Health-Related Quality of Life of Older Malay Adults Using Cut-Point For Vector Magnitude. Journal of Movement, Health \& Exercise, 13-14.

Agrina, Z. R. (2012). Efektifitas Asuhan Keperawatan Keluarga Terhadap Tingkat Kemandirian Keluarga Mengatasi Masalah Kesehatan. Journal of Movement, Health \& Exercise Keluarga, 7(2). https://doi.org/10.31258/sorot.7.2.2003

Akter, R., Samad, M. A., Zaman, F., \& Islam, M. S. (2013). Effect of weeding on the growth, yield and yield contributing characters of mungbean (Vigna radiata L.). Journal of the Bangladesh Agricultural University, 11(452-2016-35536), 53. https://doi.org/10.3329/jbau.v11i1.18209

Badan Pusat Statistik DIY. (2015). Statistik Penduduk Lanjut Usia.

Basuki, A. T., \& Prawoto, N. (2016). Analisis Regresi Dalam Penelitian Ekonomi \& Bisnis: Dilengkapi Aplikasi SPSS \& EVIEWS. Depok: PT Rajagrafindo Persada.

Chang, S. J. I. E. (2014). Development of a Situation-Specific Theory For Explaining Health-Related Quality of Life among Older South Korean Adults with Tipes 2 Diabetes. NCBI, 28(2). https://doi.org/10.1891/1541-6577.28.2.113

Choi, Y., Kim, J. H., \& Park, E. C. (2015). The effect of subjective and objective social class on health-related quality of life: new paradigm using longitudinal analysis. Health and quality of life outcomes, 13(1), 121. http://doi.org/10.1186/s12955-015-0319-0

Crouch, R., Wilson, A., \& Newbury, J. (2011). A systematic review of the effectiveness of primary health education or intervention programs in improving rural women's knowledge of heart disease risk factors and changing lifestyle behaviours. International Journal of Evidence-Based Healthcare, 9(3), 236-245.

Dinas Kesehatan Sleman Regency. (2016). No Titl.

Ding, X., Shen, Z., Zhang, C., Qi, L., Jiao, Y., \& Mao, D. (2015). Impact of health educators' intervention on non-communicable diseases-related knowledge, attitude and behavior among rural residents. Zhonghua yu fang yi xue za zhi [Chinese journal of preventive medicine], 49(12), 1098-1103.

Erawati. (2012). Pengaruh Dukungan Keluarga terhadap Pencegahan Depresi pada Lansia di Wilayah Kerja Puskesmas Denpasar Selatan I Kotamadya Denpasar Bali. Universitas Airlangga. 
Feldman, R. (2012). Discovering the Life Span (2nd ed.). New Jersey: Pearson Education, Inc.

Friedman. (2010). Keperawatan Keluarga. Jakarta.

Ghasemi, M., Hosseini, H., \& Sabouhi, F. (2019). Effect of peer group education on the quality of life of elderly individuals with diabetes: A randomized clinical trial. Iranian journal of nursing and midwifery research, 24(1), 44. https://doi.org/10.4103/ijnmr.IJNMR_39_17

Götz, D. (2010). Langenscheidt Grosswörterbuch. München: Langenscheidt KG.

Halcomb, E., Stephens, M., Bryce, J., Foley, E., \& Ashley, C. (2016). Nursing competency standards in primary health care: an integrative review. Journal of clinical nursing, 25(9-10), 1193-1205. https://doi.org/10.1111/jocn.13224

Henderson, J., Willis, E., Xiao, L., Toffoli, L., \& Verrall, C. (2016). Nurses' perceptions of the impact of the aged care reform on services for residents in multi-purpose services and residential aged care facilities in rural Australia. Australasian journal on ageing, 35(4), E18-E23. https://doi.org/10.1111/ajag.12343

Husein, U. (2013). Penelitian untuk Skripsi dan Thesis. Jakarta: Rajawali.

Kemenkes. (2015). Rencana Pembangunan Jangka Menengah Nasional Kesehatan.

Kemenkes, R. I. (2018). Riset Kesehatan Dasar; RISKESDAS. In B. RI (Ed.). Jakarta.

Saputro, S., Rustama, A., Kusnandar, I., Istiqomah, N., Khoiriyah, S., Tantri, D., \& Karyanta, N. A. (2015). Analisis Kebijakan Pemberdayaan dan Perlindungan Sosial Lanjut Usia.

Mofrad, Z. P., Jahantigh, M., \& Arbabisarjou, A. (2016). Health promotion behaviors and chronic diseases of aging in the elderly people of Iranshahr*-IR Iran. Global journal of health science, 8(3), 139. https://doi.org/10.5539/gjhs.v8n3p139

Muszalik, M. (2012). The Care Dependency Scale For Measuring Basic Human Needs: An International $\begin{array}{lllll}\text { Comparison. Journal of Advanced } & \text { Nursing, } & 10, & \text { 2341-2348. }\end{array}$ https://doi.org/10.1111/j.1365-2648.2011.05939.x

Notoatmodjo. (2013). Promosi Kesehatan Global. Jakarta.

Orem D. E. (20111). Nursing Concept of Practice (6th ed.). Missouri: Mosby Inc.

Parmar, J., Torti, J., Brémault-Phillips, S., Charles, L., Chan, K., \& Tian, P. G. J. (2018). Supporting Family Caregivers of Seniors Within Acute and Continuing Care Systems. Canadian Geriatrics Journal, 21(4), 292. https://doi.org/10.5770/cgj.21.317

Jumita, R., Azrimaidaliza, A., \& Machmud, R. (2012). Kemandirian Lansia Diwilayah Kerja Puskesmas Lampasi Kota Payakumbuh. Jurnal Kesehatan Masyarakat Andalas, 6(2), 86-94.

Skinner, B. F. (1938). The Behavior of Organisms: an Experimental Analysis. Oxford, England. Oxford: Appleton-Century.

Liu, F., Wang, C., Hu, T., \& Wang, W. (2018). S-1-based concurrent chemoradiotherapy in the treatment of locally advanced non-small cell lung cancer: A systematic review and meta-analysis protocol. Medicine, 97(15).

Sugiyono. (2014). Statistika untuk Penelitian. Bandung.

van der Vorst, A., Zijlstra, G. R., De Witte, N., Duppen, D., Stuck, A. E., Kempen, G. I., ... \& D-SCOPE Consortium. (2017). Correction: Limitations in Activities of Daily Living in Community-Dwelling People Aged 75 and Over: A Systematic Literature Review of Risk and Protective Factors. PloS one, 12(1), e0170849. http://doi.org/10.1371/journal.pone.0165127

WHO. (2015). Study on global AGEing and adult health (SAGE). National Institute on Aging National Institutes of Health. NIH Publication no.11-7737.

\section{Copyrights}

Copyright for this article is retained by the author(s), with first publication rights granted to the journal.

This is an open-access article distributed under the terms and conditions of the Creative Commons Attribution license (http://creativecommons.org/licenses/by/4.0/). 